\title{
DAKWAH KULTURAL TAKMIR MASJID ASSALAFIYAH KEDUNG BARUK PADA ACARA SELAMATAN DESA
}

\author{
Achmad Al Farisi \\ STID Al-Hadid, Surabaya \\ alfarisi@gmail.com
}

\begin{abstract}
Abstrak: Dakwah adalah upaya internalisasi, transmisi informasi dan difusi nilai-nilai Islam dari dai kepada mad'uw dengan memperimbangkan beragam aspek dari mad'uw, termasuk aspek budaya. Takmir Masjid Assalafiyah Kedung Asem, Kelurahan Kedung Baruk, Surabaya melaksanakan dakwah kultural dengan memasukkan nilai-nilai Islam pada acara tradisi Jawa selamatan desa. Kegiatan tersebut berhasil menghadirkan jemaah kurang lebih 3000 orang meskipun dilaksanakan di lingkungan perkotaan. Keberhasilan kegiatan dakwah kultural tersebut dapat menjadi pelajaran bagi masjid atau lembaga dakwah lainnya dalam pelaksanaan kegiataan dakwah kultural di masyarakat. Tulisan ini mendeskripsikan dakwah kultural dalam kegiatan selamatan desa yang diadakan takmir Masjid Assalafiyah. Dipandu oleh konsep dakwah kultural dari Acep Aripudin dan $M$. Sulthon. Tulisan ini menggunakan metode penelitian kualitatif dengan teknik analisis transkip hasil wawancara, reduksi data, analisis, interpretasi data dan triangulasi. Data diperoleh dari wawancara takmir, dokumentasi, dan observasi. Hasilnya dakwah kultural yang dilaksanakan melalui kegiatan selamatan desa merupakan akomodasi antara dua budaya yg berbeda, yaitu takmir Masjid Assalafiyah yang membawa nilai-nilai budaya Islam dan masyarakat Kedung Asem, yang kini didominasi warga pendatang dengan budaya Jawa Matraman. Bentuk interaksi yang terjadi secara umum bersifat akulturasi. Takmir Masjid berhasil memasukkan kegiatan yang bernuansa lebih Islami dalam tradisi selamatan desa Kedung Asem. Kegiatan dakwah kultural dapat digolongkan sebagai dakwah ummah dan terlaksana secara bottom-up.

Kata kunci: dakwah kultural, selamatan desa, takmir masjid.
\end{abstract}

\begin{abstract}
Da'wah constitutes an effort of internalizing and transmitting informasion and diffusion of Islamic values from dai (Islamic proselytizer) to mad'uw (Islamic adherents), including cultural aspect. The committees of mosque Assalafiyah kedung Asem, District of Kedung Baruk, Surabaya conduct cultural da'wah by inserting Islamic values in Javanese traditional ceremony of village salvation. The ceremony succeeded in gathering around 3000 people although it was conducted in an urban area. The success in conducting the cultural da'wah activity can be a lesson for other mosques and da'wah institutions in conducting cultural da'wah activities in society. The writing describes about cultural da'wah in village salvation ceremony conducted by the committees of Mosque Assalafiyah. It is guided with cultual da'wah concept by Acep Aripudin and M. Sulthon. This writing uses qualitative research method by a technique on analyzing the transcripts of interviewing, data reduction, analysis, data interpretation and triangulation. The data were taken from interviewing the
\end{abstract}


committees, documentation and observation. The result shows that cultural da'wah conducted through village salvation ceremony constitutes an accomodation between two different cultures, which are the values of Islamic culture brought by the committees of Mosque Assalafiyah and the culture of Jawa Matraman brought by most of newcomers. The form of interaction generally happened is a cultural acculturation. The committeees succeeded in inserting an activity which has more Islamic nuance into the traditon of village salvation ceremony of Kedung Asem. The cultural da'wah activity can be categorized as da'wah for people and the one conducted in bottom-up way.

Key words: cultural da'wah, village salvation ceremony, mosque's committee

\section{Pendahuluan}

Pendekatan dakwah adalah sudut pandang terhadap proses dakwah. Umumnya penentuan pendekatan didasarkan pada mitra dakwah dan suasana yang melingkupinya. ${ }^{1}$ Penetapan pendekatan dakwah adalah bentuk penyesuaian pendekatan dakwah oleh dai dengan kondisi mad'uw atau mitra dakwah. Penyesuaian tersebut termasuk dalam metode dakwah. Kondisi mad'uw yang selalu berubah dan berkembang sesuai dengan tantangan dan kebutuhan yang dihadapinya serta pengetahuan dan teknologi juga yang semakin canggih. Untuk menghadapinya para dai harus mengembangkan pendekatan yang berbeda, para dai diharapkan mengembangkan pendekatan yang kreatif dan inovatif. Salah satu contoh bentuk ijtihad tersebut adalah seperti yang dilakukan oleh para wali ketika berdakwah dan menyebarkan ajaran Islam di Indonesia dan khususnya kepada Masyarakat jawa.

Pendekatan ini pula yang berbeda diterapkan oleh wali songo ketika berdakwah di Indonesia khususnya di masyarakat Jawa. Seperti dakwah yang

${ }^{1}$ Moh. Ali Azis, Ilmu Dakwah, (Jakarta: Kencana, 2009), 347. dilakukan oleh Sunan Giri di kota Gresik yang berdakwah dengan menggunakan budaya tepatnya dengan mewujudkan gamelan sekaten, yaitu gamelan yang dibunyikan pada peringatan maulid nabi dan orangorang yang ingin melihatnya harus datang ke masjid, harus berwudhu terlebih dahulu, dan ketika memasuki masjid harus mengucapkan dua kalimat syahadat. ${ }^{2}$ Bukan hanya itu Sunan Giri juga mengarang lagu lirilir yaitu tembang jawa yang disisipi dengan ajaran Islam.

Menurut Sjahjudi Siradj mengutarakan tiga pendekatan dakwah, yaitu pendekatan budaya, pendekatan Pendidikan, dan pendekatan psikologis. Pendekatanpendekatan ini melihat lebih banyak pada kondisi mitra dakwah. ${ }^{3}$ Untuk itu penyesuaian harus dilakukan oleh komunikator (dai), media, pesan ataupun Teknik dalam menyampaikan pesan tersebut. Kondisi komunikan akan banyak ditentukan oleh budaya yang berkembang di masyarakat, pemikiran, ataupun berdasarkan permasalahan yang dihadapi oleh masyarakat. Berdakwah ke masyarakat perkotaan secara umum akan menggunakan

\footnotetext{
2 Asep Muhyidin dan Agus Ahmad Safei, Metode Pengembangan Dakwah, (Bandung: Pustaka Setia, 2002), 129.

${ }^{3}$ Azis, Ilmu Dakwah., 347.
} 
pendekatan yang berbeda ketika berdakwah ke masyarakat pedesaan. Berdakwah ke masyarakat berbeda dengan berdakwah secara personal, dikarenakan secara umum masyarakat memiliki budaya yang sudah mengakar dan menjadi kebanggaan tersendiri bagi masyarakat.

Kegiatan dakwah di perkotaan umumnya berkembang sesuai dengan budaya masyarakat urban yang cenderung modern. Namun kegiatan dakwah di salah satu wilayah di Kota Surabaya, tepatnya di wilayah Kedung Asem, Kelurahan Kedung Baruk, Kecamatan Rungkut, Kota Surabaya. Beberapa kegiatan dakwah yang berkembang di Kedung Asem seperti pengajian dengan mengundang kiai, membaca Alquran, mengkaji kitab kuning atau membaca selawat secara berjamaah. Metode dakwah yang digunakan dengan ceramah yaitu dengan mengundang pendakwah untuk mengisi ceramah salah satunya dari wilayah nderosemo ndalem. ${ }^{4}$

Menurut Ustaz Cholid Suud selaku sesepuh desa dan Wakil Ketua Takmir Masjid Assalafiyah pada masa sebelum terjadinya urbanisasi masyarakat Kedung Asem banyak mengikuti ceramah yang diisi oleh K.H. Mas Muhajir Mansur. ${ }^{5}$ Beliau mengisi ceramah, mengadakan kegiatan selawat hadrah, mengaji kitab kuning di Masjid Assalafiyah setiap minggu. Namun semakin besarnya

4 Nderosemo Ndalem terletak di Kelurahdan Sidosermo, Kecamatan Jagir, Kota Surabaya, yaitu wilayah yang banyak terdapat pesantren dan termasuk merupakan salah satu dari empat pesantren besar di Jawa. Lihat: Siti Rohmatul Musanada, Peranan K.H. Mas Muhajir Mansur Dalam Mengembangkan Pondok Pesantren An-Najiyah Sidosermo Surabaya Tahun 1942-1989 (Avatara, E-Journal Pendidikan Sejarah Volume 2, No. 1, Maret 2014). arus urbanisasi kegiatan-kegiatan tersebut banyak ditinggalkan dan tidak banyak masyarakat yang minat lagi dengan kegiatan tersebut.

Salah satu kegiatan dakwah yang berjalan di daerah Kedung Asem selain ceramah tersebut, ${ }^{6}$ adalah kegiatan haul Kiai Jiwonolo dan haul K.H. Abdurochim yang dilaksanakan sejak tahun $1978 .{ }^{7}$ Kegiatan tersebut terdiri dari ceramah agama, selawat Ishari berjamaah, ${ }^{8}$ dan tahlil mendoakan para sesepuh desa. Pada awal pengadaan kegiatannya dapat melibatkan masyarakat secara penuh, mereka terlibat ikut berselawat bersama-sama, pengadaan kegiatan bazar, dan lain-lai. Namun pada awal tahun 2000-an masyarakat Kedung Asem menjadi kurang berminat untuk mengikuti kegiatan tersebut. Menurut Ustaz Cholid Suud, ${ }^{9}$ kurangnya minat warga Kedung Asem dikarenakan adanya urbanisasi masyarakat yang banyak berasal dari luar Surabaya.

Pada tahun 2018, kegiatan haul Kiai Jiwonolo berbeda dengan pada awal tahun 2000an. Pada awal pengadaan kegiatannya pada awal tahun 2000-an warga tidak banyak terlibat. ${ }^{10}$ Namun saat proses diskusi awal pada tahun 2000-an menghadapi fenomena tersebut muncul ide agar kegiatan selawat dan haul tersebut banyak diminati oleh masyarakat maka Ustaz Cholid

\footnotetext{
5 Ustaz Cholid Suud, Wawancara oleh Penulis, Kamis 30 Agustus 2018.

${ }^{6}$ Terletak Di RW 1 Dan RW 2 Kelurahan Kedung Baruk, Kecamatan Rungkut Kota Surabaya

7 Ustaz Cholid Suud, Wawancara.

${ }^{8}$ Singkatan dari Ikatan Seni Hadrah Indonesia

9 Tokoh Masyarakat di Kedung Asem, Ketua LKMK Kelurahan Kedung Baruk Periode 2010-2015, Wakil Ketua Takmir Masjid Assalafiyah

${ }^{10}$ Ustaz Cholid Suud, Wawancara.
} 
Suud dan diprakarsai oleh takmir Masjid Assalafiyah memodifikasikan dengan ditambahkan kegiatan selamatan desa (slametan desa). Hal tersebut berefek pada semakin ramainya masyarakat yang mengikuti kegiatan haul tersebut.

Pada umumnya selamatan yang dilakukan dengan tujuan untuk mendapatkan keselamatan dari ancaman yang akan datang. Upacara ritual biasanya dilakukan secara rutin oleh sekelompok masyarakat yang diatur dengan hukum masyarakat yang berlaku, dan melibatkan para warga dalam mencapai tujuan keselamatan bersama sebagai upaya manusia untuk mencari keselamatan, ketentraman, dan sekaligus menjaga kelestarian kosmos, terhindar dari gangguan makhluk halus. ${ }^{11}$ Selamatan ini dijadikan sebagai bentuk upaya bersyukur kepada Zat yang dianggap Maha Berkuasa. Praktiknya digunakan untuk rasa syukur pada momen-momen yang dianggap penting dalam kehidupan manusia.

Menurut Clifford Gertz, acara selamatan desa dibagi menjadi empat jenis. Pertama, yang berkaitan dengan kehidupan: kelahiran, khitanan, pernikahan, dan kematian. Kedua, yang terkait dengan peristiwa perayaan Islam, misalnya Maulid Nabi. Ketiga, bersih desa ("pembersihan desa"), berkaitan dengan integrasi sosial desa. Keempat, kejadian yang tidak biasa misalnya berangkat untuk perjalanan panjang, pindah rumah, mengubah nama, kesembuhan penyakit, kesembuhan akan pengaruh sihir, terhindar dari marabahaya,

11 Bustanuddin Agus, Agama Dalam Kehidupan Manusia: Pengantar Antropologi Agama, (Jakarta: Rajawali Press, 2006), 96.

12 lbid.

${ }^{13}$ Dara Maytisa, Siany Indria Liestyasari, Dan Atik Catur Budiati, "Tayuban Dan Tradisi Bersih Desa Di Wonogiri dan sebagainya. ${ }^{12}$ Perubahan ini tidak lepas dari penyesuaian antara tradisi dengan kepercayaan yang sudah dimiliki oleh masyarakat. Tradisi selamatan desa pada umumnya lebih mengarah ke sinkretesme salah satunya pemberian sesaji ke tempattempat danyangan. ${ }^{13}$

Pelaksanaan selamatan desa yang diadakan takmir Masjid Assalafiyah ternyata berbeda dengan selamatan desa yang selama ini dipahami oleh masyarakat Jawa. Takmir Masjid Assalafiyah banyak memasukkan nilai-nilai Islam dalam setiap praktiknya. Tradisi selamatan desa di Kedung Asem dilaksanakan selama dua hari dua malam. Kegiatan tersebut diikuti dengan antusias oleh warga. Hal tersebut nampak dari jumlah peserta kegiatan yang kurang lebih 3000 orang, mulai dari anak-anak hingga orang dewasa. Pada praktiknya tradisi ini berbeda dengan selamatan desa yang umumnya kental dengan nuansa sinkretisme. Namun pada kegiatan tersebut lebih dominan nilai-nilai Islami seperti istighosah, membaca bacaan tahlil, selawat nariyah, doa bersama untuk keselamatan desa dengan doa-doa Islami yang dipimpin oleh ketua takmir masjid. ${ }^{14}$

Selain jumlah peserta yang sangat banyak, dibandingkan sebelumnya, pengadaan kegiatan selamatan desa pada tahun 2018 cukup berbeda. Takmir masjid menambahkan kegiatan khataman Alquran secara serentak di setiap mushala, yang sebelumnya belum pernah ada, dan menghilangkan panggung hiburan yang

(Studi Deskriptif Kualitatif Pada Masyarakat Dusun Sambeng, Desa Kepuhsari, Kecamatan Manyaran)." Sosialitas, Vol 5, No 2 (2015).

14 Observasi oleh Penulis, tanggal 3 Agustus 2018. 
sebelumnya ada. Dalam artian pada tahun 2018 takmir masjid memasukkan nilai-nilai ajaran Islam lebih banyak dari pengadaan sebelumnya. Dengan demikian, kegiatan dakwah kultural yang dilakukan takmir Masjid Assalafiyah dengan memasukkan nilai-nilai Islam dalam kegiatan selamatan desa, dapat dikatakan berhasil. Dengan indikasi diakomodasinya nilai-nilai Islam dalam kegiatan tersebut oleh warga, dan kehadiran jumlah peserta yang banyak. Keberhasilan tersebut dapat menjadi pelajaran bagi masjid dan lembaga dakwah lainnya dalam pelaksanaan programprogram dakwah kultural di masyarakat.

Dari latar belakang di atas, studi ini hendak mendeskripsikan dakwah kultural yang dilaksanakan oleh takmir Masjid Assalafiyah Kedung Baruk pada acara selamatan desa tahun 2018. Fokus studi ini adalah mendeskripsikan bentuk dan pelaksanaan kegiatan dakwah kulturalnya. Studi ini nantinya diharapkan memberikan khazanah baru dalam pengembangan ilmu dakwah khususnya pendekatan dakwah kultural yang melibatkan organisasi masjid dan menyasar masyarakat perkotaan yang masih kuat secara tradisi. Secara praktis kajian ini juga diharapkan dapat melengkapi studi dakwah yang kebanyakan dikaji dalam perspektif dakwah secara lisan.

Objek studi adalah kegiatan dakwah kultural dan subjek studi adalah takmir Masjid Assalafiyah Kedung Asem, Kelurahan Kedung Baruk, Kecamatan Rungkut, Kota Surabaya. Metodologi studi menggunakan jenis penelitian deskriptif kualitatif. Data dikumpulkan dengan metode wawancara mendalam, observasi partisipasi, dan analisis telaah dokumen. Prosedur analisis data yang digunakan adalah reduksi data, penyajian data dan verifikasi data. Kredibilitas penelitian dilakukan dengan uji trangulasi sumber data. Analisis data menggunakan model Miles and Huberman, yakni: (1) pengumpulan data, (2) reduksi data, (3) penyajian data, (4) penarikan kesimpulan. Informan studi ini adalah Wakil Ketua Takmir Masjid Assalafiyah, yang merupakan key informan. Informan lainnya adalah Ketua panitia kegiatan. Selain itu juga menggunakan data hasil observasi pada pra dan hari $\mathrm{H}$ acara, yaitu tanggal 1 Agustus 2018 di Masjid Assalafiyah, dan tanggal 3 dan 4 Agustus 2018. Sebagai data sekunder menggunakan dokumentasi panitia saat berlangsungnya acara.

Penelitian terdahulu yang juga mengambil tema dakwah kultural di antaranya, pertama, "Pendekatan Dakwah Kultural Dalam Masyarakat Plural," oleh Sakareeya Bungo. ${ }^{15}$ Penelitian tersebut menguraikan bentuk pendekatan dakwah kultural pada masyarakat plural. Peneliti menguraikan bagaimana konsep dakwah kultural dapat menjadi usaha dalam pembentukan manusia berada dalam nilai-nilai Islami meskipun tidak dalam struktur pemerintahan. Penelitian ini lebih utama melakukan desain pendekatan dakwah kultural dalam masyarakat plural yang tidak semua mengenal Islam. Penelitian ini tidak mendeskripsikan bentuk budaya atau perilaku dakwah kultural. 
Kedua, penelitian yang berjudul "Strategi Dakwah Kultural Pengurus Wilayah Muhammadiyah Jawa Timur" oleh Rudy Al Hana. ${ }^{16}$ Penelitian ini mendeskripsikan bagaimana dakwah kultural yang dilakukan oleh Pengurus Muhammadiyah Jawa Timur. Penelitian termasuk dalam jenis penelitian kualitatif deskriptif, dengan melakukan indepht interview. Hasil penelitian ini adalah deskripsi metode dakwah kultural yang dilakukan pengurus Muhammadiyah Wilayah Jawa Timur adalah dengan memanfaakan local wisdom dengan mendudukkannya sebagai hal yang harus dihormati dan dihargai, namun tetap mengembangkan upaya purifikasi dan menolak hal-hal yang dekat dengan sinkretisme seperti bid'ah, tahayul dan khurafat. Ketiga, "Dakwah Kultural Dalam Tradisi Hileyia Pada Masyarakat Kota Gorontalo," yang disusun oleh Erwin J. Thaib dan Andries Kango. ${ }^{17}$ Penelitian ini mengungkap bagaimana realitas tradisi hileyia dalam masyarakat Kota Gorontalo, bagaimana wujud dakwah kultural dalam tradisi hileyia, serta apa efek dakwah kultural dalam tradisi hileyia pada masyarakat Kota Gorontalo. Penelitian ini tidak hanya mendeskripsikan wujud dari dakwah kultural dalam tradisi namun juga menguraikan dampak dari dakwah yang dilakukan.

\section{Dakwah Kultural}

\section{Pengertian Dakwah Kultural}

Dakwah menurut bahasa berasal dari kata da'wah, yad'uw, da'a yang berarti

\footnotetext{
16 Rudy Al-Hana. "Strategi Dakwah Kultural Pengurus Wilayah Muhammadiyah Jawa Timur." Jurnal Komunikasi Islam. Volume 01, Nomor 02, (Desember 2011).

17 Erwin J. Thaib, Andries Kango. "Dakwah Kultural Dalam Tradisi Hileyia Pada Masyarakat Kota
}

panggilan, seruan dan ajakan. Sedangkan menurut istilah, banyak sekali definisi dakwah. Menurut Saifudin Azhari, dakwah adalah segala aktivitas yang mengubah suatu situasi lain yang lebih baik menurut ajaran Islam. Tetapi juga berupa usaha usaha meneruskan dan menyampaikan kepada perorangan dan umat. Konsepsi Islam tentang pandangan dan tujuan hidup manusia di dunia dan akhirat ini yang meliputi amar makruf nahi munkar, dengan berbagai media dan cara yang diperbolehkan akhlak yang membimbing pengalamannya dalam kehidupan perseorangan berumah tangga tangga, bermasyarakat, bernegara. ${ }^{18}$

Aktivitas dakwah melibatkan interaksi antara dai dan mad'uw yang beragam. Mad'uw sendiri yaitu sasaran dakwah, mitra dakwah atau manusia penerima dakwah sebagai individu maupun kelompok, baik manusia beragama Islam maupun tidak, atau dengan kata lain manusia secara keseluruhan. Mad'uw di suatu daerah pasti akan memiliki budaya yang berbeda-beda di setiap daerah terutama di Indonesia yang memiliki beragam suku dan budaya.

Ada beberapa pengertian budaya menurut menurut Koentjaraningrat, ${ }^{19}$ kebudayaan dengan kata dasar budaya berasal dari bahasa sansakerta "buddhayah", yaitu bentuk jamak dari buddhi yang berarti "budi" atau "akal." Jadi Koentjaraningrat mendefinisikan budaya sebagai "daya budi" yang berupa cipta, karsa dan rasa, sedangkan kebudayaan adalah hasil dari

Gorontalo." Jurnal "Al-Qalam". Volume 24 Nomor 1 Juni (2018).

18 Endang Saifuddin Anshari, M. Natsir, Islam dan Kristen di Indonesia, (Bandung: CV Bulan Sabit, 1969).

19 Koentjaraningrat, Pengantar Antropologi I, (Jakarta: Rineka Cipta, 2000), 181. 
cipta, karsa, dan rasa itu. Koentjaraningrat membedakan adanya tiga wujud dari kebudayaan yaitu: (a) wujud kebudayaan sebagai sebuah kompleks dari ide-ide, gagasan, nilai-nilai, norma-norma, peraturan dan sebagainya; (b) wujud kebudayaan sebagai suatu kompleks aktivitas serta tindakan berpola dari manusia dalam suatu masyarakat; (c) wujud kebudayaan sebagai benda-benda hasil karya manusia.

Perbedaan budaya yang dimiliki setiap masyarakat baik secara wujud kebudayaan menjadi hal yang harus diperhatikan agar dakwah berjalan dengan baik. Karena tidak jarang terjadi perbedaan antara nilai-nilai Islam dan budaya masyarakat sebagai mad'uw. Perbedaan tersebut menyebabkan nilai-nilai Islam menjadi sulit untuk diterima bahkan terjadi konflik atau pertentangan antara dai dengan mad'uw. Untuk mengantisipasi adanya pertentangan atau bahkan konflik maka terdapat pendekatan yang dapat menyelesaikan masalah tersebut yaitu dakwah kultural atau dakwah antar budaya. Ragam suku dan budaya ini pun ditegaskan oleh allah dalam surah Alhujarat ayat 13, yang artinya: "Hai manusia, sesungguhnya Kami menciptakan kamu dari seorang laki-laki dan seorang perempuan dan menjadikan kamu berbangsa-bangsa dan bersuku-suku supaya kamu saling kenalmengenal. Sesungguhnya orang yang paling mulia diantara kamu disisi Allah ialah orang yang paling takwa diantara kamu. Sesungguhnya Allah Maha Mengetahui lagi Maha Mengenal. "20

${ }^{20}$ Alquran 49: 13

${ }^{21}$ Acep Aripudin, Dakwah Antarbudaya, (Bandung: Remaja Rosdakarya, 2012), 25.
Menghindari adanya bentuk konflik dan pertentangan antar budaya yang dibawa oleh dai dan mad'uw maka secara teoritik, pendekatan dakwah menjadi salah satu solusi. Dakwah kultural memiliki istilah yang sama dengan dakwah antar budaya. Pengertian Dakwah kultural atau dakwah antar budaya pada hakikatnya adalah proses dakwah yang mempertimbangkan keragaman budaya antar dai dan mad'uw dan keragaman penyebab terjadinya gangguan interaksi pada tingkat intra dan antar budaya agar peran dakwah dapat tersampaikan dengan tetap terpeliharanya situasi damai. ${ }^{21}$

Pengertian dakwah kultural menurut Muhammad Arifin, adalah dakwah yang dilakukan dengan cara mengikuti budayabudaya kultur masyarakat setempat dengan tujuan agar dakwahnya dapat diterima lingkungan masyarakat. ${ }^{22}$ Sedangkan Samsul Munir Amin menjelaskan dakwah kultural adalah pengembangan jalur dakwah memalui jalur kultural, melalui jalur nonformal misalnya melalui pengembangan masyarakat, kebudayaan, sosial, dan bentuk non-formal lainnya. ${ }^{23}$

Dengan demikian dakwah kultural mencoba memahami potensi dan kecenderungan manusia sebagai makluk budaya, berarti memahami ide-ide, adat istiadat, kebiasaan, nilai-nilai, norma, sistem aktifitas, simbol, dan hal-hal fisik yang memiliki makna tertentu yang hidup subur dalam kehidupan masyarakat. Pemahaman tersebut kemudian dibingkai oleh pandangan dan

\footnotetext{
22 Muhammad Arifin, Klasifikasi Ayat-Ayat Al-Quran Dakwah Kontemporer Buku Cerdas Para Dai, (Surabaya: CV. Pustaka Agung Harapan. 2004), 3. 23 Samsul Munir Amiin, Rekonstruksi Pemikiran Dan Dakwah Islam, (Jakarta: Amzah, 2008),109.
} 
sistem nilai ajaran Islam yang membawa pesan rahmatan lil alamin. Misi dakwah kultural adalah upaya melakukan dinamisasi dan purifikasi. Dinamisasi bermakna sebagai kreasi budaya yang memiliki kecenderungan untuk selalu berkembang dan berubah kea rah yang lebih baik dan Islami. Sedangkan purifikasi diartikan sebagai usaha pemurnian nilai-nilai dalam budaya dengan mencerminkan nilai-nilai tauhid. ${ }^{24}$

\section{Bentuk Dakwah Kultural}

Dakwah kultural dapat di deskripsikan dalam bentuk interaksi antara dai dan mad'uw. Bentuk interkaksi ini terjadi dalam empat jenis interaksi. Wujud interaksi antar dai dan mad'uw dalam dakwah antar budaya terjelaskan dengan beberapa konsep teori, yaitu resistance theory, acculturation theory, receptie theory, complementary theory. ${ }^{25}$

Pertama resistance theory. Resistance theory mengungkapkan bahwa dalam dakwah kultural dapat terjadi adanya penentangan sikap dan penolakan atas pesan dakwah yang dibawa oleh dai dan sebaliknya, ketika terdapat proses penerimaan pesan dakwah muncul respon penolakan terhadap budaya yang lama. Dalam beberapa kemungkinan terjadinya misalnya terjadi gejolak budaya pada level mad'uw begitu juga gejolak pada diri sang dari atau gejolak antara dai dan mad'uw dalam suatu kondisi. Pada akhirnya terjadi dominasi salah satu kekuatan gagasan dan budaya baik pada mad'uw maupun dai. ${ }^{26}$ Bentuk perwujudannya adalah dalam dakwah yang dilakukan oleh Nabi

\footnotetext{
${ }^{24}$ A. Syahraeni, "Pendekatan Dakwah Kultural dalam Masyarakat Plural" Jurnal Adabiyah Vol.XIV Nomor 1, (2014)

${ }^{25}$ Aripudin, Dakwah Antarbudaya., 20.

${ }^{26}$ Ibid, 21.
}

Muhammad di kota makkah yang pada akhirnya menolak atau resisten dengan budaya yang ada sebelumnya karena dianggap bertentangan dengan nilai Islam.

Kedua acculturation theory. Acculturation theory yaitu bentuk percampuran antar budaya yang lama dengan yang baru akhirnya membentuk sebuah budaya yang diakui sebagai budaya mad'uw tanpa kehilangan identitas budaya lamanya. Menurut Koentjaraningrat akulturasi sebagai suatu proses sosial yang terjadi apabila manusia dalam suatu masyarakat dengan kebudayaan tertentu dipengaruhi oleh unsur-unsur budaya lain dan lambat laun unsur kebudayaan asing itu diakomodasikan dan diintegrasikan ke dalam kebudayaannya sendiri tanpa kehilangan kepribadian dari kebudayaannya. ${ }^{27}$

Ketiga, receptive theory (teori resepsi), menerima sepenuhnya atau menerima sebagian gagasan budaya yang lain dan baru harus menjadi budaya masyarakat setempat terlbih dahulu. Penerimaan dapat terjadi karena gagasan dan budaya baru itu dianggap lebih baik dan menjanjikan terhadap perbaikan nasib hidup masyarakat. Standar suatu budaya dapat dikatakan baik adalah apabila gagasan dan budaya itu telah teruji pada praktik masyarakat secara nyata. ${ }^{28}$ Praktik ini terjadi umumnya di masyarakat yang maju dan modern.

Keempat, complimentary theory yaitu adanya pembaruan suatu budaya masyarakat. Proses pembaruan suatu

\footnotetext{
27 Dwi Ratna Nurhajarini, Ernawati Purwaningsih, dkk, Akulturasi lintas Zaman di Lasem: perspektif sejarah dan Budaya (Kurun Niaga - Sekarang). (Yogyakarta: Balai Pelestarian Nilai Budaya (BPNB), 2015.

${ }^{28}$ Aripudin, Dakwah Antarbudaya., 22.
} 
budaya dalam teori ini adalah penerimaan budaya luar secara lambat-laun, perlahan setahap demi setahap, hingga sebagian dari budaya baru tersebut diterima, bahkan dijadikan sebagai model dalam hubungan interaksi antar masyarakat. Antara budaya lama dan budaya baru bukan saling berbenturan, tapi saling mengisi. Contohnya adalah budaya berdemokrasi di negaranegara berkembang. Interaksi yang terjadi dalam dakwah kultural ini dapat menjadikan alat ukur efek interaksi yang terjadi dalam masing-masing teori atau dapat mengungkapkan efek dari dakwah kultural itu sendiri dalam setiap bentuknya.

\section{Aktivitas Dakwah Kultural}

Aktivitas dakwah dapat diuraikan dalam bentuk aktivitas dai dan mad'uw ketika berinteraksi melakukan internalisasi, transmisi informasi dan difusi ajaran Islam, maka bentuk dakwah kultural atau dakwah dengan mempertimbangkan aspek budaya dapat dilakukan dalam konteks dakwah sebagai berikut, pertama, bentuk dakwah dengan dakwah nafsiyah, yaitu mengajak manusia dalam hal ini dirinya (ego atau keakuannya) oleh kesadaran dirinya sebagai solusi problematika konflik dalam diri individu dalam dakwah. Adapun metodemetode yang digunakan pendekatan dakwah nafsiyah antara lain: (1) wiqayah al nafsiyah (pemeliharaan diri sendiri) baik jasmani terutama rohani (memakan makanan yang bergizi dan halal, memperbanyak zikir, melakukan salat, membaca Alquran, menggali ilmu dan bergaul dengan orang-orang saleh); (2) tazkiyah al nafsiyah (mensucikan jiwa) dengan banyak merenung tentang asal diri terutama pada waktu pagi hari (salat malam/tahajud), bermuhasabah (instropeksi diri), banyak beramal shaleh, menolong dan membebaskan mustazdafin (orang-orang tertindas), mujahadah (penyaksian diri kepada allah) dan istiqlalu an-nafsi (memerdekakan diri) membebaskannya dari segala kungkungan materi tak terkecuali diri sendiri dan; (3) memenangkan quwwah alliyah (daya kecerdasan intelektual) seperti banyak membaca, berdiskusi, dan bekerja terhadap quwah al ghadhabiyah (daya kemarahan), seperti berwatak reaktif, bermalas, malasan, berprasangka, marah, buruk kepad aorang lain, sathawiyah (daya perangakap setan seperti bersenang-senang dan berfoya-foya atau prilaku hedonis, sangat cinta terhadap materi dan huburan serta mainan yang dapat melalaikan dari Tuhan.

Kedua, dakwah fardiyah (dai dan mad'uw masing-masing satu orang) bagi solusi konflik antarindividu dalam suatu budaya. Metode yang digunakan antara lain: (a) hikmah pendekatan ilmiah (jujur, berbicara sesuai objeknya, sistematis, dukungan fakta, singkat dan padat); (b) maudizah hasanah (teladan yang baik, pelajaran yang benar); (c) mujadalah bi al-lati hiya ahsan (berdiaolog, berdebat dan diskusi) tepat dilakukan ketika berhadapan dengan kaum intelek terpelajar, para alim, dan kaum pembantah; (d) ta'aruf (pertukaran budaya positif); (e) islah (perbaikan); (f) tilawah (pembacaan kebenaran universal); (g) tausiyah (saling berwasiat dalam kebaikan) termasuk didalamnya kritik konstruktif; (h) taklim (pembelajaran) persentasi dan dialog; (i) uswah hasanah (percontohan yang baik) menyatu di dalamnya bahwa ucapan dan perbuatan seirama dan sama. 
Ketiga, tablig (penyebaran informasi ajaran Islam) atau dakwah umah. Metode dakwah melibatkan interaksi yang terjadi antara dai (secara personal atau kelompok) dengan mad'uw secara kelompok. Metode yang digunakan antara lain: (a) ta'aruf (pertukaran budaya) atas dasar kebebasan memilih; (b) taawun al-birr (saling tolong menolong dalam kebaikan); (c) ta'alau ila kalimatin sawa (berpegang pada kalimat persamaan); (d) diyatul khair (propaganda kebaikan); (e) tabsyir (pemberian penghargaan); (f) tasyhir (pembuktian kebenaran); (g) inzdar dan sirajan munira (peringatan dan penyuluhan); (h) muhasabah fi al-dunya ma'rufa (bekerjasama dalam urusan duniawi); (i) tsamuh walatasubu ma'budahum (toleransi tidak saling mencacai); (j) ijtinab (saling menghindari pertengkaran dan perbuatan setan); (k) lakum dinukum waliyadin (sepakat dalam perbedaan keyakinan/agree indisagreement); (I) a'maluna wa a'malukum (tegas dalam memegang prinsip; dan (m) amar ma'ruf nahi mungkar (menegakkan kearifan dan mencegah kerusakan). Untuk memperjelas ketiga aktivitas dakwah tersebut dapat dijelaskan dalam tabel berikut. ${ }^{29}$

Tabel 1 - Penjelasan Ketiga Kategori Aktivitas Dakwah

\begin{tabular}{c|l|c|c|c|c}
\hline Kategori & \multicolumn{1}{|c|}{ Dai } & Pesan & Metode & Media & \multicolumn{1}{c}{ Mad'uw } \\
\hline Dakwah Nafsiyah & Seorang Diri Sendiri $(\neq)$ & $*$ & + & $*$ & Seorang Diri Sendiri $(\neq)$ \\
Dakwah Fardiyah & Satu Orang $(=\neq)$ & $*$ & + & $*$ & Satu Orang $(=\neq)$ \\
Dakwah Ummah & $\begin{array}{l}\text { Satu Orang } \\
\text { Satu Kelompok }\end{array}$ & $*$ & + & $*$ & $\begin{array}{l}\text { Kelompok/Masyarakat } \\
(=\neq)\end{array}$ \\
\hline
\end{tabular}

Keterangan:

- $\quad\left(^{*}\right)$ pesan: berisikan ajaran Islam sesuai dengan prioritas kebutuhan mad'uw

- (+) Metode: mengacu pada sebutan dalam metode dakwah intra dan antar budaya, begitu pula media

- (=) menunjukkan budaya seragam/sama

- (₹) menunjukkan budaya yang berbeda.

\section{Proses Pelaksanaan Dakwah Kultural}

Proses pelaksanaan dakwah kultural berbeda dengan dakwah secara struktural. Dakwah kultural dilaksanakan dengan pendekatan bottom up atau dari atas kebawah, sedangkan dakwah secara struktural dilaksanakan dengan pendekatan up bottom atau dari atas kebawah. Penerapan dakwah dalam budaya lokal memerlukan beberapa tuntutan, pertama, pengenalan dengan baik berbagai aspek ajaran agama, termasuk pesan-pesan dasarnya. Kedua, pengenalan dengan baik kebudayaan lokal dan segala seluk beluk kehidupan masyarakat, termasuk bahasa, adat istiadat, kesusasteraan, seni, pandangan hidup, dan gambaran dunia. Ketiga, pengenalan dengan baik kenyataan masa kini masyarakat, perubahanperubahan yang sedang terjadi dan fenomena yang timbul. Keempat,

\footnotetext{
29 Ibid, 44.
} 
penguasaan sejarah dan penggunaan imajinasi kreatif. ${ }^{30}$

Bentuk pelaksanaan dari dakwah kultural dikonseptualisasikan sebagai berikut, $^{31}$ pertama, dakwah harus dimulai dengan mengetahui kebutuhan masyarakat. Yang dimaksud kebutuhan adalah kebutuhan akan nilai-nilai yang dibutuhkan secara objektif dari yang Nampak atau berdasakan dari proses telaah atau penelitian mendalam. Kedua, dakwah dilakukan dengan pendekatan partisipasi dari bawah. Maksudnya bahwa ide yang ditawarkan mendapatkan kesepakatan masyarakat atau berasal dari ide masyarakat sendiri, bukan berasal dari perintah atau arahan yang lebih tinggi. Ketiga, dakwah dilaksanakan melalui proses sistematika pemecahan masalah. Artinya program dakwah yang dilakukan oleh masyarakat sejauh mungkin diproses menurut langkah-langkah pemecahan masalah. Keempat, dakwah memanfaatkan teknologi yang sesuai dengan tepat guna. Maksudnya adalah menggunakan teknologi yang sesuai dengan keterjangkauan, pengetahuan dan keterampilan masyarakat. Kelima, program dakwah dilaksanakan melalui tenaga dai yang bertindak sebagai motivator, baik dilakukan oleh tenaga terlatih dari lembaga atau organisasi masyarakat yang berpartisipasi maupun dari luar daerah yang adaptif. Keenam, program dakwah tersebut didasarkan atas asas swadaya dan kerjasama masyarakat. Dimaksudkan bahwa pelaksanaan program dakwah harus berangkat dari kemampuan diri sendiri dan merupakan kerjasama dari potensi-potensi yang ada. Ketujuh, dakwah

30 Syahreini, "Pendekatan Dakwah." Adabiyah.

${ }^{31}$ Muhammad Sulthon, Menjawab Tantangan Zaman: Desain IImu Dakwah Kajian Ontologis, Epistemologis, dilakukan secara terpadu, artinya pelaksanaan dakwah kultural melibatkan berbagai unsur yang ada dalam masyarakat dan penyelenggaraan program dakwah.

Dengan demikian dapat dikonseptualisasikan bahwa dakwah kultural akan mewujudkan interaksi antara nilai Islam dengan budaya lokal, bentuk pertama dapat terjadi pertentangan dengan masing-masing budaya atau resistensi antara budaya lama dan baru (resistence theory), kemudian dapat juga terjadi pembauran (akulturasi), penerimaan salah satunya (reception) sehingga menimbulkan hegemoni nilai budaya, atau terjadi perpaduan yang saling mengisi (komplementer). Secara teknis dapat terbentuk dalam berbagai aktivitas dakwah mulai dari dakwah nafsiyah, dakwah fardiyah, dan dakwah umah. Proses pelaksanaannya dilakukan dengan pendekatan bottom up.

\section{Masyarakat Wilayah Kedung} Asem

Kedung Asem adalah istilah yang digunakan masyarakat, wilayah ini terletak di kelurahan kedung baruk. Tepatnya terletak di wilayah RW 1 dan RW 2 kelurahan kedung Baruk, kecamatan Rungkut, Kota Surabaya. jika melihat data statistik tingkat Pendidikan masyarakat kelurahan kedung baruk tingkat Pendidikan masyarakat tertinggi adalah tingkat pendidikan SD dengan jumlah 5.376 orang. Sedangkan pendidikan SMP sejumlah 4.924; pendidikan SMA sejumlah 4.493, dan perguruan tinggi sejumlah 554 untuk

dan Aksiologis, (Semarang: Walisongo Press, 2003), 536. 
berpendidikan diploma, 1.196 yang berpendidikan sarjana. ${ }^{32}$ Dapat dikatakan masyarakat Kelurahan Kedung Baruk termasuk wilayah Kedung Asem, mayoritas tingkat pendidikannya adalah menengah ke bawah. Secara pekerjaan mayoritas di dominasi pekerjaan Swasta dengan jumlah 4.753 orang. ${ }^{33} \mathrm{Hal}$ tersebut sejalan dengan hasil pengamatan Ustaz Cholid suud yang mengatakan bahwa mayoritas penduduk Kedung Asem adalah pekerja atau buruh pabrik yang bekerja di kawasan SIER (Sentra Industri Ekonomi Rungkut). Menurut pengamatan Ustaz Cholid Suud, mayoritas masyarakat yang datang dan baru tinggal di Kedung Asem berasal dari daerah luar Kota Surabaya, berasal dari daerah Jawa Timur Matraman seperti Ngawi, Magetan, Madiun, Ngawi, Kediri, dan Ponorogo. Masyarakat mataraman masih kental dengan budayabudaya Jawa seperti selamatan desa.

\section{Tradisi Selamatan Desa di Kedung Asem}

Sejak tahun 1978 hingga tahun 2000-an terdapat tradisi kegiatan haul Kiai Jiwonolo dan K.H. Abdurohim dan selawat Ishari di wilayah Kedung Asem. Pada saat tahun 2001 terjadi penurunan jumlah partisipasi masyarakat dalam kegiatan tersebut. Hal tersebut berlangsung hingga beberapa tahun, hingga takmir masjid saat itu mengutarakan ide untuk memodifikasi acara tersebut dengan acara selamatan desa. Ide tersebut disambut oleh masyarakat terutama masyarakat pendatang. Usulan takmir masjid yang diwakili oleh Ustaz Cholid Suud diterima namun dengan syarat

\footnotetext{
32 Badan Pusat Statistik Kota Surabaya, Kecamatan Rungkut Dalam Angka 2017, 19. https://surabayakota.bps.go.id/publication/2017/09/
}

tetap mempertahankan tradisi Jawa seperti mengadakan pesta, kirab ke batas desa dan mengadakan kegiatan sedekah bumi. ${ }^{34}$ Pada rapat dengan warga pada tahun 2001, akhirnya disepakati bahwa kegiatan haul dan selawat Ishari tetap dilaksanakan, namun dikemas dengan menambahkan tradisi selamatan desa dengan teknis bersih desa, sedekah bumi, dan tradisi pesta mengundang penyanyi, serta mendirikan panggung di sisi selatan dan utara desa.

Dalam perkembangan pada tahun 2018, tradisi pesat mengundang penyanyi dengan mendirikan panggung (orkes dangdut) di sisi selatan dan utara desa di hilangkan. Hal tersebut disepakati dalam rapat yang diadakan pada 30 Juni 2018. Acara orkes dangdut yang dianggap sebagai hal yang kurang Islami diganti dengan khataman Alquran serentak di dua belas musala di wilayah Kedung Asem.

Pada mulanya menurut penjelasan panitia, kegiatan selamatan desa tahun 2018 sama dengan tahun sebelumnya, yaitu dengan serangkaian acara istighosah kubro, kirab dan bersih desa pada hari pertama, dan hari kedua selawat Ishari, bazar rakyat dan terdapat panggung hiburan yang mengundang penyanyi dangdut atau orkes. Dalam rapat panitia yang diselenggarakan untuk itu, pada mulanya peserta rapat setuju dengan usulan tersebut. Namun terdapat beberapa usulan dari masyarakat, pertama usulan dari tokoh masyarakat yaitu dengan mengganti acara orkes diganti dengan acara tradisi Jawa seperti tari-tarian atau reog, dan usulan kedua berasal dari

26/556218c3864ba70f53c049fc/kecamatan-rungkutdalam-angka-2017.html.

33 Ibid, 21.

34 Ustaz Cholid Suud, Wawancara. 
ketua takmir masjid yang mengusulkan kalau orkes tidak sesuai dengan nilai-nilai Islam diganti dengan dengan kegiatan khataman Alquran serentak di musala pada hari kedua. Usulan dari ketua takmir tersebut kemudian di terima oleh peserta rapat saat itu.

Hari pertama dilaksanakan pada hari tanggal 3 Agustus 2018. Pelaksanaan acara selamatan desa dimulai dengan kegiatan bersih desa, yaitu dengan membersihkan halaman masing-masing dan tentu saja halaman masjid. Kegiatan bersih-bersih lingkungan dilakukan oleh seluruh masyarakat Kedung Asem secara bersamaan. Kegiatan dilanjutkan dengan istighosah kubro yaitu masyarakat secara bersama-sama berkumpul di Masjid Assalafiyah kemudian di mulai dengan bacaan Alquran surah Yassin sebanyak tiga kali, dan bacaan Istighosah yang dipimpin oleh Ustaz As'ad Ichya' dan K.H. Luthfi Akbar. $^{35}$ Pasca itu seluruh peserta kendurenan $^{36}$ makan bersama makanan yang berasal dari warga Kedung Asem. Pasca kendurenan seluruh peserta melanjutkan kegiatan dengan melakukan kirab dengan membawa obor mengelilingi desa. Rute kirab pertama dari Masjid Assalafiyah menuju batas desa sebelah Utara tepatnya di Jalan Kedung Asem sebelah utara Gang 9 Kedung Asem. Kegiatan kirab obor mengelilingi desa dengan diiringi dengan selawat Nariyah menuju tiga batas desa, batas utara, selatan dan barat. Saat rombongan kirab sampai pada batas desa perwakilan rombongan mengumandangkan azan, membaca bacaan selawat Nariyah, bacaan tahlil, ayat kursi dan doa bersama untuk keselamatan desa. Kegiatan bersih desa dan kirab obor di akhiri dengan kegiatan tahlil kubro yang dipimpin oleh pemuka agama di makam desa tepat di dekat makam Kiai Jiwonolo. ${ }^{37}$ Berikut beberapa dokumentasi acara selamatan desa:

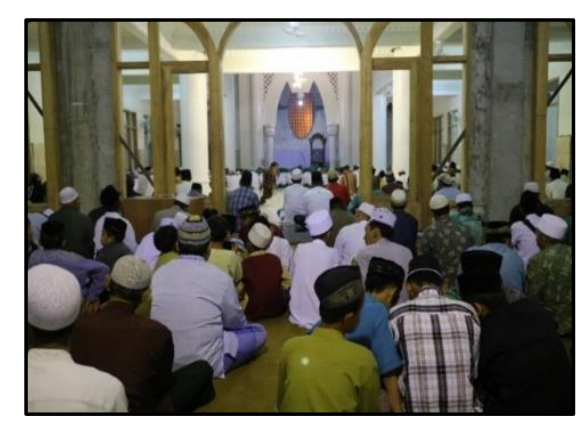

Gambar 1 - Suasana di Masjid Assalafiyah saat Pembukaan Acara Selamatan Desa dengan Istighosah Kubro

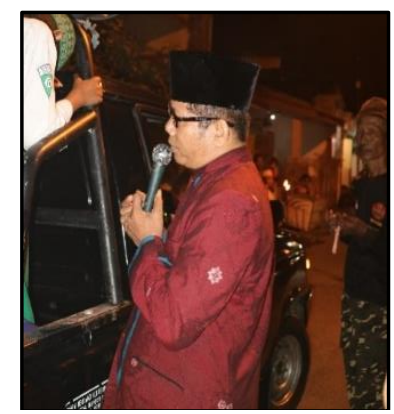

Gambar 2 - Ketua Takmir Masjid Assalafiyah Membacakan Doa di Batas Desa

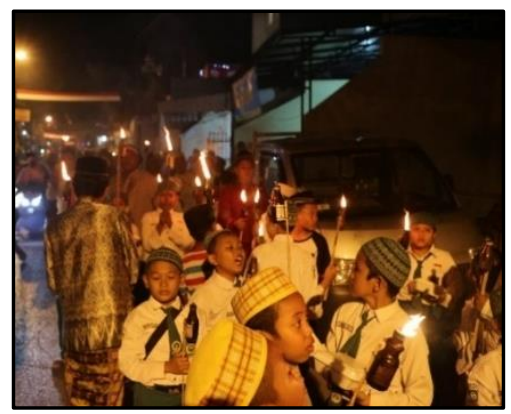

Gambar 3 - Peserta Kirab Selamatan Desa Berhenti di Batas Desa Sebelah Utara
35 Beliau merupakan Rois Suriah PAC NU Kecamatan Rungkut Surabaya.
${ }^{36} \mathrm{KBBI}$ ofline v.1.5 "Kenduri berarti perjamuan makan untuk memperingati peristiwa, minta berkat, dsb; selamatan:

${ }^{37}$ Observasi oleh Penulis, Tanggal 3 Agustus 2018. 
Acara hari kedua, yaitu tepatnya pada Hari Sabtu tanggal 4 Agustus 2018. Kegiatan di mulai dengan acara khataman Alquran serentak di dua belas musala dan masjid di wilayah Kedung Asem yang dimulai setelah sholat subuh hingga selesai. Kemudian dilanjutkan dengan dengan kegiatan masyarakat menyiapkan makanan sesuai dengan makanan yang biasa dimakan oleh keluarga. Setiap keluarga mengumpulkan minimal lima porsi makanan ke koordinator yang ditunjuk untuk selanjutnya makanan tersebut akan diberikan kepada para peserta selawat Ishari.

Pasca Isya kegiatan dimulai dengan pembukaan dan penyampaian sejarah awal mula kegiatan yang disampaikan oleh Ustaz Cholid Suud sebagai salah satu sesepuh desa dan wakil ketua takmir masjid. Materi yang berkaitan dengan sejarah desa seperti siapa yang pertama kali mendirikan desa, melakukan syiar agama Islam di desa Kedung Asem dan bagaimana sejarah dari kegiatan selamatan desa. Menurut beliau, tujuan pemberian wawasan tentang sejarah desa adalah untuk mengingatkan dan untuk menjaga ingatan masyarakat akan sejarah para pendiri desa dan sesepuh desa agar dapat menghargai dan menjaga desa dengan baik. ${ }^{38}$ Selain itu Ustaz Cholid Suud juga menyampaikan beberapa materi keagamaan seperti pentingnya menghargai jasa para pahlawan dan menghormati guru dan sesepuh desa.

Kegiatan ceramah dan penjelasan tentang sejarah desa dihadiri oleh pejabat di lingkungan kelurahan Kedung Baruk, sekertaris Kecamatan Rungkut, Bimaspol, Babinsa dan beberapa pengurus RT ataupun

38 Ustaz Cholid Suud, Wawancara.
RW di lingkungan Kedung Baruk. Selain itu juga dihadiri oleh masyarakat dari kalangan jemaah tahlil dan jemaah Masjid Assalafiyah dan pengurus musala di lingkungan Kedung Asem. Pasca ceramah kemudian Camat dan Lurah bergantian menyampaikan sambutan terhadap kegiatan.

Pasca pembukaan, penyampaian sejarah dan ceramah agama, maka para undangan peserta dari anggota Ishari perwakilan cabang se-Jawa Timur membacakan bacaan selawat dengan iringan tabuhan rebana. Kegiatan selawatan berlangsung hingga pukul 02:00 WIB. Tamu undangan yang hadir dari berbagai kota di Jawa Timur, seperti dari Sidoajo, Pasuruan, Gresik, Lumajang, dan Surabaya. Pasca selawatan para tamu diberikan makanan yang berasal dari warga. Pemberian makanan ini disebut sebagai bentuk syukur dan wujud lain dari sedekah bumi namun tidak dilarung atau diletakkan di tempat keramat tapi diberikan kepada tamu yang sudah mendoakan desa. ${ }^{39}$

\section{Dakwah Kultural Dalam Tradisi Selamatan Desa Kedung Asem.}

Dari uraian di atas dapat dipahami bahwa pendekatan dakwah kultural yang ditempuh takmir Masjid Assalafiyah didasari keadaan madúw-nya, yaitu masyarakat Kedung Asem. Masyarakat Kedung Asem sebagai pasar dakwah, awalnya adalah warga asli yang secara kultural tidak jauh berbeda dengan pengurus masjid. Namun seiring dengan perkembangan, banyak warga pendatang atau urban. Terjadi perbedaan budaya berupa dari masyarakat asli dan masyaakat pendatang. Jika mengacu pada

39 lbid. 
konsep budaya yang berwujud dari ide-ide atau gagasan, nilai atau norma, tindakan pola perilakunya. Masyarakat pendatang secara mayoritas banyak yang berasal dari wilayah Jawa matraman, dimana nilai-nilai kebudayaan Jawa masih relatif terjaga. DI antaranya seperti budaya selamatan. Hal tersebut berpengaruh pada kultur warga pendatang masyarakat Kedung Asem, perilaku masyarakat cenderung lebih suka dengan kegiatan seperti selamatan desa, kemudian pesta mengundang penyanyi, dan lain-lain.

Corak budaya tersebut berimplikasi pada minat masyarakat pada kegiatan dakwah yang diselenggarakan Masjid Assalafiyah. Saah satunya adalah kegiatan dakwah yang dilaksanakan dalam bentuk peringatan haul, pengajian dan berselawat bersama-sama, yang lambat laun mengalami jumlah penurunan. Untuk mencapai tujuan yang diharapkan yaitu kegiatan dakwah tetap berlangsung dan semarak setiap tahunnya, pada tahun 2001 takmir Masjid Assalafiyah melakukan desain ulang terhadap kegiatan dakwah yang dilaksanakan setahun sekali tersebut. Kegiatan selawat dan haul dilaksanakan namun ditambahkan dengan acara selamatan desa. Hal tersebut karena takmir menyadari bahwa budaya masyarakat Kedung Asem dipengaruhi nilai budaya Jawa, salah satunya adalah tradisi selametan. Saat proses desain ulang tersebut melibatkan warga dan tokoh masyarakat Kedung Asem, dan diputuskan pelaksanaan selamatan desa dengan mengadakan pesta, kirab ke batas desa dan mengadakan kegiatan sedekah bumi, namun tetap mempertahankan kegiatan selawat Ishari dan haul.

Selamatan bersih desa menurut Clifford Grertz berhubungan dengan pengkudusan hubungan dalam ruang dengan merayakan dan memberikan batas-batas kepada salah satu unit territorial dasar dari struktur social orang jawa. Apa yang ingin dibersihkan dari desa itu tentu saja adalah makhluk-makhluk halus yang berbahaya. Ini dilakukan dengan mengadakan selamatan dimana hidangan dipersembahkan kepada dayang desa ("makhluk halus penjaga desa") di tempat pemakamananya. ${ }^{40}$ Kegiatan selametan desa yang dilaksanakan terdiri dari tiga praktik tradisi, yaitu kegiatan bersih desa, kirab desa, dan sedekah bumi. Pelaksanaan selametan dilaksanakan oleh masjid dan melibatkan masyarakat dalam pelaksanaannya. Tradisi selametan desa dilaksanakan selama dua hari dua malam.

Pada pelaksanaan kegiatan dakwah yang dilakukan takmir Masjid Assalafiyah mencoba menggunakan jalan damai dikarenakan adanya perbedaan budaya antara takmir selaku dai dengan masyarakat Kedung Asem yang mayoritas berbeda budaya karena termasuk pendatang baru yang membawa budaya Jawa mataraman. Perbedaan dalam sisi budaya pada praktik budaya antara takmir dan masyarakat desa berjalan dengan baik. Hal ini sejalan dengan konsep dakwah kultural atau dakwah antar budaya, dimana proses dakwah yang dilakukan harus mempertimbangkan keragaman budaya antar dai dan mad'uw dan keragaman penyebab terjadinya

40 Clifford Geertz, Agama Jawa: Abangan, Santri, Priyayi dalam kebudayaan jawa. Cetakan kedua (Depok: komunitas Bambu, 2014), 109. 
gangguan interaksi pada tingkat intra dan antar budaya agar peran dakwah dapat tersampaikan dengan tetap terpeliharanya situasi damai.

Kemudian jika di telaah lebih lanjut dilihat dalam sudut pandang bentuk dakwah kultural (empat jenis teori interaksi, yaitu resistensi akulturasi, penerimaan, dan perpaduan) maka tradisi selamatan desa sendiri dapat disebut sebagai bentuk akulturasi budaya antara budaya Islam tradisi dengan Jawa. Kegiatan selamatan desa yang awalnya secara praktiknya menurut Suwardi waktu pelaksanaannya yaitu satu tahun sekali, biasanya sesudah musim panen padi. Terkait soal bulan, hari, tanggal, dan cara pelaksanaannya tidak selalu sama antara satu desa dengan desa yang lain. Tempat penyelenggaraan bersih desa dan pesta desa mengikuti kebiasaan desa setempat, ada kegiatan yang merata dilakukan di seluruh lingkungan desa beserta penghuninya, disamping itu juga ada kegiatan yang dipusatkan pada tempattempat tertentu, yaitu: (1) tradisi puncak dipusatkan di balai desa; (2) pesta desa dipusatkan di lapangan desa setempat; (3) sedekah misalnya dilaksanakan di makam leluhur; (4) sesaji dan doa dilakukan di makam atau petilasan cikal bakal desa. ${ }^{41}$

Pelaksanaan kegiatan selamatan dan bersih desa yang dilakukan di Kedung Asem secara prinsip memiliki beberapa kemiripan, yaitu menggunakan masjid sebagai pusat tempat acara, melakukan doa di tempat yang dianggap penting seperti makam leluhur dan batas desa. Namun yang menjadi berbeda adalah secara isi, yaitu isi dari acara tidak melakukan pesta seperti pada

\footnotetext{
${ }^{41}$ Maytisa, dkk. Tayuban dan., 6.
}

umumnya tapi melakukan istighosah kubro. Dari sesajen tidak lagi adakan melainkan diganti dengan makanan yang diberikan kepada peserta yang mengikuti acara. Doa dan sesajen juga diganti dengan berdoa bersama kepada Allah SWT dan bukan kepada leluhur atau selaiinya. Dari bentuk praktik tradisi baru ini diterima sebagai bentuk tradisi masyarakat Kedung Asem karena sudah berjalan sejak tahun 2001 hingga tahun 2018. Sehingga dapat dikatakan sebagai bentuk akulturasi budaya.

Demikian pula dengan kegiatan bersih desa. Menurut Muriatmono, upacara bersih desa selalu didahului dengan membersihkan desa dari segala kotorannya yaitu sampahsampah harus dibersihkan, membersihkan got-got saluran air agar lancar pengairannya, membenahi pagar halaman dan sebagainya, sehingga kampung kelihatan bersih, rajin, dan dalam suasana menyenangkan. Kebersihan di makam juga dilakukan, di makam tidak ada acara khusus yang ada hanya mengirim doa. Pelaksanaan kebersihan di makam ini dilakukan oleh warga desa secara gotong royong. ${ }^{42}$ Tradisi ini juga dilakukan dalam serangkaian kegiatan selamatan desa di Kedung Asem. Namun karena tidak memiliki unsur yang berbeda dengan nilai-nilai Islam maka secara teknis pun sama. Sehingga dalam hal ini terjadi proses penerimaan budaya. Praktik bersih desa dalam rangkaian acara selamatan desa diterima sepenuhnya sebagai bagian dari kegiatan dakwah takmir Masjid Assalafiyah.

Dalam rangkaian selanjutnya yaitu tradisi sedekah bumi. Tradisi ini diwujudkan dengan cara warga atau setiap keluarga

42 Ibid. 
mengumpulkan makanan sejumlah lima untuk di sajikan kepada para peserta selawat sebagai bentuk representasi dari ucapan terimakasih karena sudah turut mendoakan dan berselawat di Kedung Asem. Praktik tradisi ini secara teknis berbeda dengan tradisi sedekah bumi di masyarakat Jawa pada umumnya. Di beberapa daerah, sedekah bumi masih kental dengan ritual yang mempersekutukan Allah SWT. Ritual sedekah bumi secara umum memiliki dua prosesi. Pertama adalah pakem ritual dan yang kedua adalah prosesi pengiring. Pakem ritual berupa prosesi ritual sesaji yang dilakukan di punden dusun. Sedangkan prosesi pengiring berupa arak-arakan sesaji, ritual sesaji di Balai Kelurahan, tandhakan, gulat okol, pengajian dan ludrukan. Tidak semua prosesi pengiring dilaksanakan semua, tetapi bisa bergantian. Sesaji yang dihidangkan baik sebagai sesembahan atau untuk dihidangkan kepada masyarakat adalah hasil bumi seperti nasi atau beras hasil panen, sayur-sayuran, buah-buahan dan polo pendem. Saat dilaksanakannya ritual sesaji di pepunden dusun, yang menjadi pemimpin doa atau mantra adalah sesepuh dusun, sedangkan warga hanya mengikuti doa dari sesepuh dusun. ${ }^{43}$

Secara praktik sedekah bumi di desa kedung asem memiliki bentuk kegiatan yang berbeda namun memiliki beberapa kemiripan dan akhirnya diakui menjadi budaya masyarakat kedung asem. Pertama disebabkan karena pekerjaan dari masyarakat kedung asem yang sudah hampir tidak ada lagi pekerjaan sebagai

43 Robert Tajuddin dan Agus Trilaksana, "Perubahan Tradisi Ritual Sedekah Bumi di Kota Metropolitan Surabaya: Analisa Perubahan Tradisi Ritual Sedekah petani. Secara teknis bentuk sedekah bumi tidak lagi di berikan dalam bentuk sesajen atau makanan yang di jadikan gunungan yang kemudian di arak keliling desa. Secara makanan yang di sajikan pun tidak berupa hasil alam seperti beras hasil panen, sayursayuran, buah-buah atau polo pendem. Secara praktik, ketua RT akan menyampaikan informasi kepada warga melalui selebaran dan secara langsung kepada warga untuk membuat makanan yang di tempatkan di wakul atau kotak. Menu makanannya disesuaikan dengan makanan yang biasa dimakan atau di sajikan kepada tamu secara pantas. Dengan demikian terjadi modifikasi atau peleburan budaya menjadi budaya baru dengan kemiripan, pengumpulan makanan dilakukan namun dirubah dengan tujuan yang berbeda, maka hal ini menjadikan praktik sedekah bumi menjadi bentuk akulturasi budaya dalam kegiatan dakwah yang dilakukan oleh takmir Masjid Assalafiyah.

Praktik yang ketiga yaitu merubah kegiatan pesta saat selamatan desa sebelumnya sering dilaksanakan, namun pada tahun 2018 diganti dengan khataman Alquran serentak di dua belas musala di Kedung Asem. Hal ini jika diuraikan dengan teori interaksi sesuai dengan resistensi terhadap budaya lama yang dianggap bertentangan dan diganti dengan budaya baru yang lebih baik. Anggapan bahwa mengundang penyanyi dan mendirikan panggung di beberapa tempat di desa memberikan dampak negatif, sedangkan khotmil quran dianggap sebagai hal yang positif sehingga

Bumi di Dusun Jeruk Kelurahan Jeruk Kecamatan Lakarsantri Kota Surabaya Tahun 1990-2014," Avatara, Vol. 3, No. 3 (Oktober, 2015), 432. 
dilakukanlah penolakan terhadap budaya lama yang dianggap buruk.

Dakwah yang kultural yang dilakukan oleh takmir masjid lebih menyasar kepada bentuk prilaku berjamaah yang melibatkan warga dan masyarakat muslim di desa secara keseluruhan, baik anak-anak, orang dewasa laki-laki, dan perempuan. Bentuk dakwah kultural yang dilakukan takmir Masjid Assalafiyah termasuk bentuk dakwah ummah. Secara konsep dakwah umah atau tablig (penyebaran informasi ajaran Islam) dari dai bisa seorang atau kelompok. Kemudian secara pesan, metode, dan media yang digunakan menyesuaikan dengan kebutuhan mad'uw.

Jika diuraikan lebih lanjut tentang dai dalam kegiatan selamatan desa, pelaksanaannya dilaksanakan secara kelompok yaitu oleh takmir Masjid Assalafiyah. Mad'uw yang disasar juga kelompok masyarakat. Secara jenis dakwah berupa: (a) ta'aruf (pertukaran budaya) atas dasar kebebasan memilih dalam akulturasi kegiatan dakwah selamatan desa; (b) taawun al-birr (saling tolong menolong dalam kebaikan) spesifiknya dilaksanakan dalam kegiatan sedekah bumi. Sehingga praktik dakwah kultural takmir masjid assalafiyah termasuk dalam bentuk dakwah umah.

Terwujudnya tradisi sebagai dakwah kultural ini tidak lepas dari adanya upaya dalam menjaring aspirasi masyarakat dan melibatkan dalam setiap kegiatan dan pengambilan keputusan. Pelaksanaan dan penetapan bentuk kegiatan juga melihat adanya kebutuhan masyarakat akan bentuk dakwah yang menyesuaikan dengan konteks masyarakat Kedung Asem yang banyak dari kalangan masyarakat pendidikan rendah dan masyarakat pendatang. Dai dalam kegiatan ini menjadi motivator dan hanya sebagai pendorong bukan sebagai pihak yang terlibat penuh dalam setiap tahapannya. Pelaksanaan kegiatan mulai dari pembuatan asahan, membuat obor, menyediakan makanan, membersihkan desa. Semua dilaksanakan secara gotong royong dan sukarela, dai hanya menyampaikan nilai penting dan manfaat dengan adayan tradisi selamatan desa bagi desa dan para penghuninya. Kegiatan ini juga melibatkan perangkat pejabat di desa seperti RT dan RW juga terlibat aktif.

Sehingga kegiatan dakwah kultural ini melibatkan masyarakat dari sejak proses perumusan kegiatan apa saja yang akan dilakukan dengan media rapat kampung yang diadakan di masjid. Kemudian dakwah yang dilakukan mendapatkan partisipasi dari masyarakat bawah dan dilakukan atas dasar kesepakatan. Dalam pengumpulan makanan berhasil terkumpul sejumlah 3000 bungkus dan hal tersebut merupakan hasil swadaya masyarakat dilakukan secara terpadu melibatkan pemerintah dengan kapasitasnya seperti memberikan izin, memberikan fasilitas penutupan jalan dan lain sebagainya. Sehingga dalam pelaksanaannya lebih berprinsip bottom-up.

\section{Kesimpulan}

Kegiatan dakwah yang dilakukan takmir Masjid Assalafiyah dengan menggunakan kultur selamatan desa merupakan bentuk dakwah kultural. Takmir Masjid Assalafiyah menyadari perbedaan kultur dengan madúw. Adanya perbedaan budaya dalam bentuk prilaku dan aktifitas terutama masyarakat pendatang yang mayoritas Jawa matraman sedangkan takmir masjid 
assalafiyah dengan Islam tradisinya. Terjadinya akulturasi dalam tradisi selamatan berupa bersih desa dan sedekah bumi, dengan adanya peleburan berupa praktik selamatan desa yang sudah dirubah sedemikian rupa namun dapat diterima dan diakui sebagai budaya masyarakat Kedung Asem, dan terjadi adanya resistensi terhadap budaya lama berupa pesta dengan mendungan orkes diganti dengan khotmil quran yang kemudian dapat diterima karena nilai manfaatnya.

Dari praktik dakwah kultural diatas menggunakan bentuk dakwah ummah, yaitu yang dilaksanakan oleh takmir masjid selaku dai dengan berkelompok, materi dakwah, dengan spesifik jenis dakwah ta'aruf (pertukaran budaya) kebebasan memilih antara budaya yang diakulturasikan dan taawun al-birr (saling tolong menolong dalam kebaikan) dalam praktik sedekah bumi. Kemudian secara pelaksanaannya melibatkan masyarakat dari awal hingga akhir dan termasuk jenis pendekatan dakwah dengan bottom-up.

Rekomendasi dari hasil studi ini adalah diharapkan pada masjid dan berbagai lembaga dakwah senantiasa memperhatikan aspek kultural madúw-nya. Dari situ para aktivis dakwah dapat mengembangkan berbagai kreasi budaya sebagai bentuk dinamisasi dakwah sekaligus upaya purifikasi apabila dijumpai nilai-nilai yang bertentangan dengan ajran Islam, namun tetap dilakukan dengan pendekatan kebudayaan.

\section{Bibliografi}

Azis, Moh. Ali. Ilmu Dakwah. Jakarta: Kencana, 2009.

Muhyidin, Asep dan Safei, Agus Ahmad. Metode Pengembangan Dakwah. Bandung: Pustaka Setia, 2002.

Musanada, Siti Rohmatul. "Peranan K.H. Mas Muhajir Mansur Dalam Mengembangkan Pondok Pesantren An-Najiyah Sidosermo Surabaya Tahun 1942-1989." Avatara, E-Journal Pendidikan Sejarah Volume 2, No. 1, (Maret 2014).

Agus, Bustanuddin. Agama Dalam Kehidupan Manusia: Pengantar Antropologi Agama. Jakarta: Rajawali Press, 2006.

Maytisa, Dara; Liestyasari, Siany Indria; dan Budiati, Atik Catur. "Tayuban Dan Tradisi Bersih Desa Di Wonogiri (Studi Deskriptif Kualitatif Pada Masyarakat Dusun Sambeng, Desa Kepuhsari, Kecamatan Manyaran)." Sosialitas, Vol. 5, No 2 (2015).

Bungo, Sakareeya. "Pendekatan Dakwah Kultural Dalam Masyarakat Plural." Jurnal Dakwah Tabligh, Vol. 15, No. 2, (Desember 2014).

Al-Hana, Rudy. "Strategi Dakwah Kultural Pengurus Wilayah Muhammadiyah Jawa Timur." Jurnal Komunikasi Islam. Volume 01, Nomor 02, (Desember 2011).

Thaib, Erwin J. dan Kango, Andries. "Dakwah Kultural Dalam Tradisi Hileyia Pada Masyarakat Kota Gorontalo." Jurnal Al-Qalam, Volume 24 Nomor 1 Juni (2018). 
Anshari, Endang Saifuddin. M. Natsir, Islam dan Kristen di Indonesia. Bandung: CV Bulan Sabit, 1969).

Koentjaraningrat. Pengantar Antropologi I. Jakarta: Rineka Cipta, 2000.

Aripudin, Acep. Dakwah Antarbudaya. Bandung: Remaja Rosdakarya, 2012.

Arifin, Muhammad. Klasifikasi Ayat-Ayat Al-Quran Dakwah Kontemporer Buku Cerdas Para Dai. Surabaya: CV. Pustaka Agung Harapan, 2004.

Amiin, Samsul Munir. Rekonstruksi Pemikiran Dan Dakwah Islam. Jakarta: Amzah, 2008.

Syahraeni, A. "Pendekatan Dakwah Kultural dalam Masyarakat Plural" Jurnal Adabiyah Vol.XIV Nomor 1, (2014).

Nurhajarini, Dwi Ratna., Purwaningsih, Ernawati. Dkk. Akulturasi lintas Zaman di Lasem: perspektif sejarah dan Budaya (Kurun Niaga - Sekarang). Yogyakarta: Balai Pelestarian Nilai Budaya (BPNB), 2015.

Sulthon, Muhammad. Menjawab Tantangan Zaman: Desain Ilmu Dakwah Kajian Ontologis, Epistemologis, dan Aksiologis. Semarang: Walisongo Press, 2003.

Badan Pusat Statistik Kota Surabaya, Kecamatan Rungkut Dalam Angka 2017. https://surabayakota.bps.go.id/publication/2017/09/26/556218c3864ba70f53c049fc/ke camatan-rungkut-dalam-angka-2017.html.

Geertz, Clifford. Agama Jawa: Abangan, Santri, Priyayi dalam Kebudayaan Jawa. Cetakan Kedua. Depok: komunitas Bambu, 2014.

Tajuddin, Robert dan Trilaksana, Agus. "Perubahan Tradisi Ritual Sedekah Bumi di Kota Metropolitan Surabaya: Analisa Perubahan Tradisi Ritual Sedekah Bumi di Dusun Jeruk Kelurahan Jeruk Kecamatan Lakarsantri Kota Surabaya Tahun 1990-2014," Avatara, Vol. 3, No. 3 (Oktober, 2015). 